\title{
Mechanisms of bronchopulmonary dysplasia
}

\author{
Antonia P. Popova
}

Received: 18 December 2012 / Accepted: 2 January 2013 / Published online: 20 January 2013

(C) The International CCN Society 2013

\begin{abstract}
Bronchopulmonary dysplasia (BPD) is a chronic lung disease affecting premature infants with long term effect on lung function into adulthood. Multiple factors are involved in the development of BPD. This review will summarize the different mechanisms leading to this disease and highlight recent bench and clinical research targeted at understanding the role of the mesenchyme (both its cellular and extracellular components) in the pathogenesis of BPD.
\end{abstract}

Keywords Bronchopulmonary dysplasia $\cdot$ Extracellular matrix $\cdot$ Growth factors $\cdot$ Hyperoxia $\cdot$ Lung development . Prematurity

\section{Introduction}

First described by Northway and colleagues in 1967 (Northway et al. 1967), bronchopulmonary dysplasia (BPD) is a chronic lung disease which develops in premature infants. Most of these infants suffered from surfactant deficiency (respiratory distress syndrome, or RDS) and subsequent lung injury due to some combination of oxygen toxicity, mechanical ventilation, inflammation and infection. The term BPD was chosen to emphasize the involvement of all tissues of the lung in the pathologic process. Pathologic findings included inflammation, airway fibrosis and smooth muscle hypertrophy, alveolar collapse and hyperinflation and interstitial fibrosis (Bonikos et al. 1976). Infants frequently died of respiratory failure.

In the past two decades, advances in perinatal care including antenatal steroid therapy, surfactant use, novel ventilator strategies and aggressive treatment of patent ductus arteriosus, have led to increased survival of very preterm newborns

A. P. Popova $(\bowtie)$

Department of Pediatrics, University of Michigan Medical School, 1150 W. Medical Center Dr., Room 3570, MSRBII, Box 5688, Ann Arbor, MI, USA 48109-5688

e-mail: antoniap@med.umich.edu
(Fanaroff et al. 2007). Increased survival, in turn, has led to increase in the incidence of BPD. In 2009, there were $3,987,108$ singleton live births in the U.S., of which $1.6 \%$ were very preterm $(<32$ weeks gestation) and $1.1 \%$ had very low birth weight $(<1,500 \mathrm{~g})$ (Martin et al. 2011). Over $25 \%$ of premature infants with birth weights $<1,500 \mathrm{~g}$ develop BPD (Jobe and Bancalari 2001). Thus, there are over 10,000 new cases of BPD annually. Today's surviving premature infants have different lung pathology, defined as "new BPD," with preserved airway structure and homogeneous lung inflation. However, there are also larger and fewer alveoli, as well as poorly formed secondary crests, indicating interference with septation (Hussain et al. 1998; Coalson 2003). Infants with BPD are more likely to be hospitalized in the first year of life and to require medications for pulmonary disease (Furman et al. 1996; Greenough et al. 2001; Ehrenkranz et al. 2005). There is broad agreement that survivors have abnormal lung function even as adults (Kennedy 1999; Eber and Zach 2001), making BPD a leading cause of pediatric lung disease.

Over the years, with the change in lung pathology and clinical presentation, different definitions of BPD have been used. In a 1979 workshop, BPD was defined as 28 days of oxygen therapy with radiographic changes (Tooley 1979). Later, an oxygen requirement at 36 weeks postmenstrual age was used as a better predictor of long terms respiratory outcomes (Shennan et al. 1988). In 2000, a workshop organized by the National Institute of Child Health and Human Development, the National Heart, Lung and Blood Institute, and the Office of Rare Diseases defined diagnostic criteria for BPD based on gestational age ( $<32$ weeks versus $\geq 32$ week) and severity (mild, moderate or severe based on oxygen supplementation at 28 days of age and 36 weeks postmenstrual age) (Jobe and Bancalari 2001). A limitation of these definitions is that criteria for oxygen administration may vary among different centers. To minimize the variations introduced by different practices for oxygen use, a new physiologic definition of BPD was recently described using a stepwise timed oxygen reduction test (Walsh et al. 2003). 
The development of BPD is a complex interaction between normal growth and developmental patterns superimposed with acute and chronic responses to environmental factors deleterious to the lung. Understanding the underlying mechanisms of BPD may provide insight into development of new therapeutic and preventive strategies. In recent years, the molecular and cellular basis of BPD has been studied, primarily using animal models. Human studies of premature infants have provided additional understanding of the different factors involved.

The lung at 24 to 26 weeks gestation is in the late canalicular stage of development. Transition to the saccular stage (starts at 26-28 weeks) and alveolar stage (starts at 36 weeks) is defined by a rapid increase in lung volume and alveolar surface area (Langston et al. 1984). Beginning at about 28 weeks, the complexity of the saccules increases, secondary crests begin to form. Extensive vasculogenesis within the developing terminal saccules occurs, along with a decline in airspace wall thickness. By 36 weeks alveoli are uniformly present and the total number of alveoli increases exponentially in proportion to gestational age. In a premature infant, this process is disrupted by prenatal and/or postnatal inflammatory processes, particularly injury due to supplemental oxygen and volutrauma.

\section{Oxygen- and ventilation-mediated lung injury}

The structure of the lung in the canalicular and saccular stages of development, together with the mechanics of the respiratory system, do not provide an optimal environment for adequate ventilation and gas exchange: diffusion of oxygen and carbon dioxide through the thickened airspace walls is limited; surfactant deficiency decreases lung compliance. The highly compliant chest wall of the premature infant exerts insufficient outward recoil, contributing to low functional residual capacity and respiratory failure. Thus, to sustain physiological function, a higher concentration of inspired oxygen and/or mechanical ventilation must be used. In addition to the benefit provided by these modalities, their injurious effects have been extensively studied. The role of hyperoxia in the pathogenesis of BPD has been reviewed extensively (Bhandari 2010; Saugstad 2010). Animal studies have shown that hyperoxia alone can arrest septation of lungs in the saccular stage of development (Coalson et al. 1995; Warner et al. 1998). Infants with BPD who were exposed to higher levels of supplemental oxygen to achieve higher levels of oxygen saturation were found to have more persistent lung disease (The STOP-ROP Multicenter Study Group 2000). Recent studies have shown that even short term exposure to hyperoxia affects the developing lung. When infants born between 24 and 28 weeks gestation were resuscitated in the delivery room with $30 \%$ instead of $90 \%$ oxygen, the incidence of BPD at 36 weeks gestation was reduced from $37.7 \%$ to $15.4 \%$ (Vento et al. 2009). Hyperoxia is a powerful proinflammatory stimulus. Infants exposed to $90 \%$ oxygen have significantly elevated TNF- $\alpha$ and IL- 8 levels (Vento et al. 2009). Oxygen toxicity is mediated through reactive oxygen species (ROS). Antioxidants have been considered as possible preventive or therapeutic options for BPD (Asikainen and White 2004; Welty and Smith 2001, 2003). Some antioxidant defenses, such as glutathione peroxidase, are greater in the premature neonate than in the adult, while other defenses, such as catalase, are lower in neonates (Asikainen et al. 1998).

Mechanical ventilation alone in animal models can interfere with lung development and induce lung phenotype reminiscent of BPD (Coalson et al. 1999; Albertine et al. 1999; Mokres et al. 2010). Mechanical ventilation at high lung volumes (by stretching normal and deceased alveoli) and low lung volumes (by periodic opening and closing of distal airspaces during ventilation with a reduced functional residual capacity) may cause ventilator-induced lung injury (Dreyfuss and Saumon 1998). Preterm lambs subjected to large tidal-volume ventilation show upregulation of multiple proinflammatory markers including IL-1 $\beta$, IL-6, IL-8, and Toll-like receptors 2 (TLR-2) and 4 (TLR-4) (Hillman et al. 2007). Strategies to minimize ventilator induced lung injury due to conventional mechanical ventilation have been developed, including volume-targeted ventilation (Cheema and Ahluwalia 2001) and early discontinuation of positive pressure ventilation and substitution with continuous positive airway pressure (CPAP) (SUPPORT Study Group of the Eunice Kennedy Shriver NICHD Neonatal Research Network et al. 2010).

\section{Role of inflammation or infection}

The role of inflammation and infection in the pathogenesis of BPD has been reviewed extensively (Jobe 2003; Speer 2003; Li and Tullus 2002) and will not be discussed in detail. Elevated levels of IL-6 and IL-8 precede the influx of neutrophils observed in RDS (Munshi et al. 1997) and may be the initiators of the inflammatory cascade that predisposes to the development of BPD (Kotecha et al. 1996). Preterm infants developing BPD demonstrate higher numbers of inflammatory cells - neutrophils and macrophages, in their bronchoalveolar lavage fluid compared with infants who recovered from RDS (Merritt et al. 1983; Arnon et al. 1993; Groneck et al. 1994). Previous studies have examined the role of neutrophils and macrophages in the pathogenesis of neonatal hyperoxic lung injury. In neonatal rats, hyperoxia induces neutrophil influx and hypoalveolarization which is attenuated by neutralizing antibodies against the neutrophil chemoattractants CXCL1 (Auten et al. 2001) or CXCL2 (Deng et al. 2000). Neutrophilic inflammation in hyperoxia is also prevented by a selective chemical antagonist of CXCR2 (Yi et al. 2004). Neutralizing antibodies against CCL2, a monocyte chemoattractant, also decrease lung 
hypoalveolarization, as well as lung macrophage and neutrophil counts, in hyperoxia-exposed rats (Vozzelli et al. 2004).

$\mathrm{NF}-\mathrm{KB}$ signaling in activated fetal lung macrophages disrupts airway morphogenesis (Blackwell et al. 2011). In fetal mouse lungs, chorioamnionitis stimulates angiogenesis and inflammatory lung phenotype reminiscent of the inflamed lungs of infants developing BPD (Miller et al. 2010). In addition to proinflammatory lung phenotype, antenatal infection (chorioamnionitis) in sheep causes lung maturation (Kramer et al. 2009). The question about a relationship between antenatal infection (chorioamnionitis) and respiratory outcomes of prematurely born infants remains unsettled. (Laughon et al. 2009; Soraisham et al. 2009; Been et al. 2010).

\section{Genetic risk factors}

Genetic influences in the development of BPD have also been considered. An early twin study by Parker et al. (Parker et al. 1996) reported that, for twin pairs with birth weights less than $1,500 \mathrm{~g}$, the BPD status of the first twin was a highly significant predictor of BPD in the second twin, independent of birth weight, gestational age, gender, severity of RDS, PDA and other potentially significant risk factors, suggesting that genetic factors are affecting the susceptibility of very low birth weight premature infants to BPD. In a study of 450 sets of twins born at less than 32 weeks of gestation, after controlling for covariates, genetic factors accounted for $53 \%$ of the variance in liability for BPD (Bhandari et al. 2006). A number of studies have reported on potential candidate genes, including polymorphisms in surfactant protein (Weber et al. 2000; Makri et al. 2002; Rova et al. 2004; Pavlovic et al. 2006) and tumor necrosis factor-alpha genes (Kazzi et al. 2004; Strassberg et al. 2007). From the large number of genes involved in normal lung growth and development, it is likely that other specific sequence variations may also be recognized in the future.

\section{Role of peptide growth factors}

Various epithelium- and mesenchyme-derived peptide growth factors and other molecules are involved in continuous crosstalk during normal lung development. The establishment of a localized domain in the ventral wall of the anterior foregut expressing the transcription factor $N k \times 2-1$ (also known as $T t f 1)$ is the earliest known step in the development of the respiratory system. Within this domain, at E9.5 in the mouse and $\sim 28$ days in the human, the two primary lung buds appear. This specification is regulated by mesoderm derived Wnt and fibroblast growth factor (FGF) signals (Goss et al. 2009; Serls et al. 2005). Once the primary lung buds form, they extend into the surrounding mesenchyme, beginning the process of branching morphogenesis. The development of the lung buds is dependent on localized expression of FGF10 in the mesoderm overlying the buds and Fgfr2 in the endoderm (Min et al. 1998; Sekine et al. 1999). At the distal tip of the branching endoderm and the surrounding mesoderm, a core group of evolutionary conserved signaling pathways, including bone morphogenic protein (BMP)/transforming growth factor (TGF)- $\beta$, Wnt, Sonic hedgehog (Shh) and retinoic acid, establish a signaling network (Cardoso and $\mathrm{Lu} \mathrm{2006).} \mathrm{The}$ different pathways cross-regulate one other. For example, Shh stimulates Wnt2 and Bmp4 in the mesenchyme (Pepicelli et al. 1998), Wnt7b/ $\beta$-catenin signaling promotes the expression of Bmp4 and Fgfr2 in the epithelium (Rajagopal et al. 2008; Serls et al. 2005) and Fgf9 (secreted by both the early epithelium and the mesothelium) promotes the expression of Fgf1 0 in the distal mesoderm (del Moral et al. 2006). During the saccular and alveolar stages of lung development, the functional units for gas exchange develop. The timing of alveolar development varies between species. In mice it occurs postnatally ( P5-30), whereas in humans some alveoli are formed before birth and the process continues for many months or years afterwards. A critical role for the Fgf pathway in alveolar development is demonstrated by the phenotype of lungs of Fgfr3/Fgfr4 double null mice that fail to undergo secondary septation (Weinstein et al. 1998). Retinoic acid receptor- $\beta$ deficient mice have defects in distal airspace development and a progressive loss of respiratory function (Snyder et al. 2005). In mice, PDGF-A, which signals solely through PDGF-R $\alpha$, is required for secondary alveolar septal formation and elastic fiber deposition (Boström et al. 1996).

Vascular growth factor signaling has been closely linked to alveolarization. Impaired signaling of growth factors involved in vasculogenesis and angiogenesis (e.g. vascular endothelial growth factor) plays a role in the development of BPD in the preterm baboon model (Maniscalco et al. 2002) and in human infants (Bhatt et al. 2001; Lassus et al. 2001). During lung injury and repair, these peptide growth factors, in combination with other growth factors involved in the acute response to injury and repair, may erroneously (spatially and temporally) exert their effect, leading to abnormal tissue architecture and impaired function.

In the remainder of this review, we will focus on role of transcription factors, signaling molecules, extracellular matrix proteins and matricellular proteins within the cellular and matrix components of the lung mesenchyme, and discuss their implication in the pathogenesis of BPD.

Role of the mesenchyme - mesenchymal cells, myofibroblasts, extracellular matrix and matricellular proteins

In early mouse embryonic lung explants, soluble factors released by peripheral lung mesenchyme can induce ectopic branching from the trachea, as well as induce expression of 
genes specific to peripheral lung epithelium, including surfactant protein (SP)-A, -B, -C and Clara cell-specific $10 \mathrm{kD}$ protein (CC-10) (Shannon 1994). Progenitor cells in the distal lung mesoderm expressing Pdgfr $\alpha$ and the transcription factors Twist 2, Foxf1 and Tbx4 are multipotent. During development, they are exposed to a series of signals, including Shh, Bmps, Wnts, VEGF, Pdgfs, FGFs, TGF $\beta$ and retinoic acid, which regulate commitment to different specialized cell types, including pericytes, parabronchial smooth muscle, myofibroblasts and lipofibroblasts.

In addition to the cellular component, the lung mesenchyme is composed of fibrous structural proteins (mainly type I and IV collagen, elastin, fibronectin and laminin), glycosaminoglycans, proteoglycans and matricellular proteins. Elastin and collagen provide the supportive structure for the airways and alveolar spaces. Fibronectin and laminin fascilitate linking of cells to the larger fibrillar proteins of the matrix. Alterations in mesenchyme-associated proteins and growth factors and their receptors, e.g., fibroblast growth factors (FGF7, FGF10, FGFR-2, -3, -4), epidermal growth factors, transforming growth factor $\beta$, connective tissue growth factor and vascular endothelial growth factor, have been associated with the development of impaired alveolarization (Ahlfeld and Conway 2012). The role of the mesenchymal cells and their interaction with matricellular proteins, non-structural extracellular matrix proteins that regulate cell-matrix interactions, thereby influencing fiber deposition, adhesion, migration, proliferation, and survival will be discussed below.

Recent studies have drawn attention to the role of mesenchymal cells in lung development and neonatal lung disease, in support of Northway and colleagues' emphasis that all lung tissues are involved in the pathologic process of developing BPD (Northway et al. 1967). As lung saccules form, there is distal spread of platelet-derived growth factor receptor- $\alpha$ expressing myofibroblasts from more proximal airway sites to the tips of secondary alveolar septa (Boström et al. 1996; Lindahl et al. 1997). These cells, which express $\alpha$-smooth muscle actin and elastin, are required for alveogenesis (Noguchi et al. 1989; Boström et al. 1996; Lindahl et al. 1997; McGowan and Torday 1997; Wright et al. 1999; Yamada et al. 2005; McGowan et al. 2008). During normal lung development, a second type of interstitial cell, containing intracellular lipids, are present at the bases of the developing septa (Vaccaro and Brody 1978). These lipofibroblasts mediate the uptake and trafficking of lipid to the type II cells for surfactant phospholipid synthesis (Schultz et al. 2002; Torday et al. 1995). By contrast, hyperoxia-exposed lungs with arrested alveolar development show a paucity of $\alpha$-actinpositive myofibroblasts at the septal tips (Hirakawa et al. 2007) and an increase in the number of $\alpha$-smooth muscle actin-, transforming growth factor (TGF)- $\beta$-positive interstitial myofibroblasts (Toti et al. 1997; Bhatt et al. 2001;
Kaarteenaho-Wiik et al. 2002; Kaarteenaho-Wiik et al. 2004). Overexpression of TGF- $\beta$ in neonatal mouse lungs induces proliferation of $\alpha$-actin-positive cells within the alveolar septal walls and hypoalveolarization (Vicencio et al. 2004), implying a critical role for TGF- $\beta$ in the development of BPD. Together, these data suggest that, in BPD, there is impaired mesenchymal cell migration combined with abnormal proliferation and differentiation.

We have isolated mesenchymal stromal cells (MSCs) from the tracheal aspirates of premature infants with respiratory distress syndrome. These cells undergo TGF- $\beta$ induced myofibroblastic differentiation and may also be stimulated to undergo adipocytic differentiation (Hennrick et al. 2007), suggesting that these cells may represent a common progenitor of the two alveolar mesenchymal cell subtypes. Neonatal lung MSCs are almost never isolated from the tracheal aspirates of infants with good pulmonary outcomes, whereas approximately half of the infants from whom MSCs are isolated develop BPD (Popova et al. 2010). Low passage unstimulated MSCs from infants developing BPD show a higher $\alpha$-actin content when compared to MSCs from infants not developing this disease, suggestive of more advanced myofibroblastic differentiation. GSK- $3 \beta / \beta$-catenin signaling, which has been implicated in myofibroblastic differentiation in vitro (Armstrong and Esser 2005; Haq et al. 2003) is upregulated in cells from infants developing BPD. Similar changes are found in lungs of infants with BPD (Popova et al. 2012). These findings suggest that GSK- $3 \beta / \beta$-catenin signaling pathway is activated in lung mesenchymal cells from patients with BPD and may play an important role in the pathogenesis of neonatal lung injury.

The GSK-3 $\beta / \beta$-catenin pathway may be initiated (and GSK-3 $\beta$ kinase activity suppressed) by a number of physiologic stimuli, including TGF- $\beta$, Wnts, Shh, BMPs, cardiotrophin, endothelin, serotonin (Deng et al. 2008; Deng et al. 2010) and the matricellular protein CCN2 (also called connective tissue growth factor or CTGF) (Fig. 1). In addition to their independent effects, matricellular proteins enhance TGF- $\beta$ receptor binding and downstream signaling responses (Abreu et al. 2002), and are required for a subset of TGF- $\beta$ responses (Snider et al. 2008)(Fig. 2). Like TGF- $\beta$ (Vicencio et al. 2004), CCN2 overexpression during development results in a lung phenotype analogous to BPD (Wu et al. 2009). CCN2 and another matricellular protein, SPARC (for Secreted Protein, Acidic, Rich in Cysteine) are early markers of fibrosis in various diseases and lung injury models (Leask et al. 2009; Wu et al. 2008; Chang et al. 2010; Strandjord et al. 1999). Neonatal lung mesenchymal stromal cells have high levels of mRNAs encoding matricellular proteins, including CCN2, SPARC and periostin (Bozyk et al. 2011).

$\mathrm{CCN} 2$ is a cysteine-rich protein possessing a secretory signal peptide, a non-functional IGF binding domain, a 


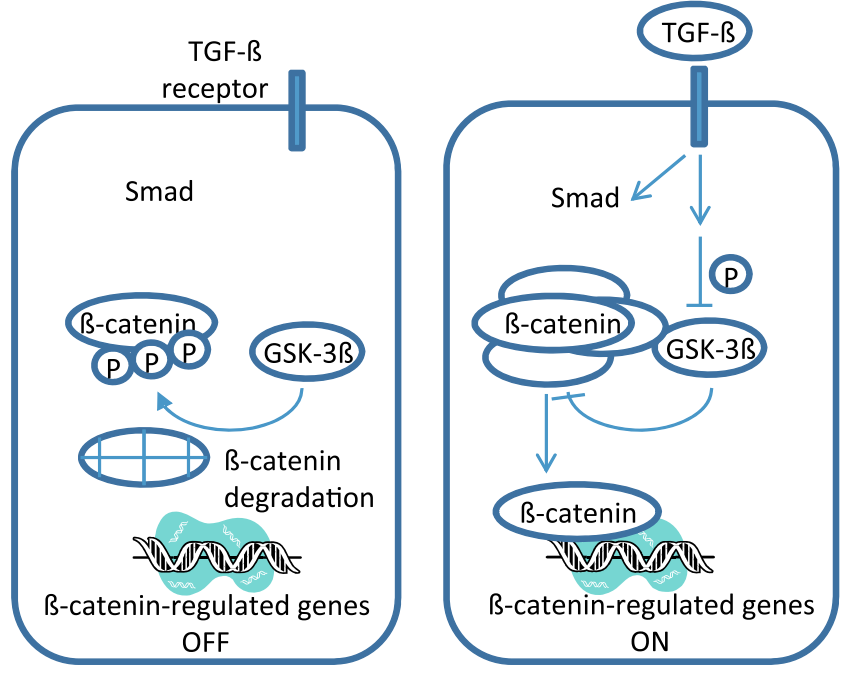

Fig. 1 GSK-3 $\beta$, a constitutively-active kinase normally phosphorylates $\beta$-catenin. Phosphorylation of $\beta$-catenin targets it for degradation, thereby preventing gene expression of regulated genes (e.g. $\alpha$-actin, collagen, fibronectin, laminin, matrix metalloproteinases, VEGF). Phosphorylation of GSK-3 $\beta$ inactivates it, allowing $\beta$-catenin to accumulate in the cytoplasm, translocate to the nucleus, and activate gene expression

VonWillebrand factor-like domain for TGF- $\beta$ binding, a thrombospondin-like domain for binding to sulfated glycoconjugates, and a heparin-binding cysteine knot domain which binds the cell surface and allows dimerization. In Mink lung epithelial cells and embryonic fibroblasts, $\mathrm{CCN} 2$ enhances binding of TGF- $\beta$ to its three receptors and is required for a subset of TGF- $\beta$ responses, inducing a cellular response not achieved by either factor alone (Abreu et al. 2002; Shi-wen et al. 2006). Conversely, TGF- $\beta$ is required for a subset of CCN2 responses (Qi et al. 2005; Sohn et al. 2006). Overexpression of CCN2 in respiratory epithelial cells during the neonatal period induces thickening of the alveolar septa, decreased secondary septal formation, myofibroblast differentiation (Wu et al. 2009) and pulmonary hypertension (Whitehead et al. 2006). CCN2 expression is increased within $30 \mathrm{~min}$ of

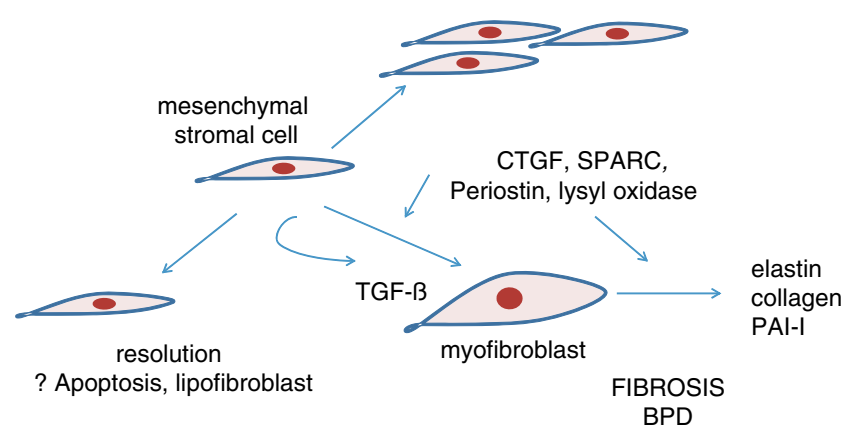

Fig. 2 Proliferation and myofibroblastic differentiation of mesenchymal stromal cells, mediated by matricellular proteins such as CCN2 and periostin, leads to fibrosis and development of BPD. (Apoptosis or adipogenic differentiation lead to resolution of lung injury.) mechanical ventilation in preterm lambs (Wallace et al. 2009) and after high tidal volume ventilation in newborn rat lungs (Wu et al. 2008). Hyperoxic exposure increases lung CCN2 mRNA and protein expression, not only in epithelial cells, but in lung mesenchyme and thickened alveolar interstitia. (Popova et al. 2012). Overexpression of CCN2 in mouse lungs also increases whole lung $\mathrm{Ser}^{9}$ GSK$3 \beta$ phosphorylation and nuclear localization of $\beta$-catenin, and $\mathrm{CCN} 2$ induces $\beta$-catenin nuclear translocation in primary alveolar type II epithelial cells (Whitehead et al. 2006). CCN2 induces GSK-3 $\beta$ phosphorylation and $\beta$ catenin accumulation in neonatal lung MSCs, and CCN2 expression is also increased in the lungs of infants with BPD. Together, these data are consistent with the notion that $\mathrm{CCN} 2$, perhaps in combination with TGF- $\beta$, is responsible for GSK- $3 \beta / \beta$-catenin signaling and myofibroblastic differentiation observed in neonatal mice, as well as in human infants with BPD (Popova et al. 2012).

SPARC is a secreted extracellular matrix glycoprotein possessing an N-terminal secretory signal peptide, a combined follistatin-like region and acid protease-like inhibitor region and a collagen-binding region. SPARC allows efficient incorporation of collagen into extracellular matrix and formation of mature, insoluble fibers by diminishing its association with cell surfaces, favoring its degradation by cell surface-associated collagenases (Rentz et al. 2007). SPARC is increased in fibroblasts from patients with idiopathic pulmonary fibrosis (Chang et al. 2010) and required for maximum collagen accumulation in bleomycin-treated mice (Strandjord et al. 1999).

Periostin is a secreted protein with an N-terminal secretory signal sequence and 4 fasciclin domains. It directly interacts with other extracellular matrix proteins and is a ligand for $\alpha v \beta 3, \alpha v \beta 5$ and $\alpha 4 \beta 6$ integrins. In the heart, periostin is induced by TGF- $\beta$ but also required for normal TGF- $\beta$ responsiveness (Snider et al. 2008). Periostin promotes myofibroblast differentiation of palmar fascia mesenchymal cells ( $\mathrm{Vi}$ et al. 2009) and is a component of subepithelial fibrosis in asthma (Takayama et al. 2006). Lysyl oxidase, which crosslinks collagen and elastin, is proteolytically activated by CCN2 and periostin (Hong et al. 1999; Maruhashi et al. 2010). Lung lysyl oxidase immunoreactivity is increased in BPD (Kumarasamy et al. 2009). We examined the role of periostin in hyperoxia-induced neonatal lung injury. Hyperoxic exposure of neonatal mice increases alveolar wall periostin expression, particularly in areas of interstitial thickening. Periostin colocalizes with $\alpha$-smooth muscle actin, suggesting synthesis by myofibroblasts (Bozyk et al. 2012). A similar pattern is found in lung sections of infants dying of BPD. Periostin knockout mice are protected from hyperoxia-induced alveolar simplification and show absence of $\alpha$-smooth muscle-positive interstitial myofibroblasts. Compared to hyperoxia-exposed wild-type mice, hyperoxia-exposed periostin null mice also 
showed reduced mRNA expression of $\alpha$-smooth muscle actin, elastin, CXCL1, CXCL2, CCL4. Together, these data suggest that excess periostin deposition promotes hyperoxia-induced lung inflammation in neonatal mice. In addition, these data show that, in addition to mediating lung fibrosis, periostin may regulate lung inflammation.

\section{Summary}

Alterations in lung development following premature birth involve a complex interplay between cellular and molecular components with diverse structural (epithelial, mesenchymal or vascular) origins. Both resident and recruited cells of hematogenous origin participate. The use of advanced molecular and genomic techniques has improved the understanding of these interactions and provides a source for future therapeutic or preventive strategy development.

\section{References}

Abreu JG, Ketpura NI, Reversade B, De Robertis EM (2002) Connective-tissue growth factor (CTGF) modulates cell signalling by BMP and TGF- $\beta$. Nat Cell Biol 4:599-604

Ahlfeld SK, Conway SJ (2012) Aberrant signaling pathways of the lung mesenchyme and their contributions to the pathogenesis of bronchopulmonary dysplasia. Birth Defects Res A Clin Mol Teratol 94:3-15

Albertine KH, Jones GP, Starcher BC, Bohnsack JF, Davis PL, Cho S, Carlton DP, Bland RD (1999) Chronic lung injury in preterm lambs. Am J Respir Crit Care Med 159:945-958

Armstrong DD, Esser KA (2005) Wnt/ $\beta$-catenin signaling activates growth-control genes during overload-induced skeletal muscle hypertrophy. Am J Physiol Cell Physiol 289:C853-C859

Arnon S, Grigg J, Silverman M (1993) Pulmonary inflammatory cells in ventilated preterm infants: effect of surfactant treatment. Arch Dis Child 69:44-48

Asikainen TM, Raivio KO, Saksela M, Kinnula VL (1998) Expression and developmental profile of antioxidant enzymes in human lung and liver. Am J Respir Cell Mol Biol 19:942-949

Asikainen TM, White CW (2004) Pulmonary antioxidant defenses in the preterm newborn with respiratory distress and bronchopulmonary dysplasia in evolution: implications for antioxidant therapy. Antioxid Redox Signal 6:155-167

Auten RL, Mason SN, Tanaka DT, Welty-Wolf K, Whorton MH (2001) Anti-neutrophil chemokine preserves alveolar development in hyperoxia-exposed newborn rats. Am J Physiol Lung Cell Mol Physiol 281:L336-L344

Been JV, Rours IG, Kornelisse RF, Jonkers F, de Krijger RR, Zimmermann LJ (2010) Chorioamnionitis alters the repsonse to surfactant in preterm infants. J Pediatr 156:10-15.e1

Bhandari V (2010) Hyperoxia-derived lung damage in preterm infants. Semin Fetal Neonatal Med 15:223-229

Bhandari V, Bizzarro MJ, Shetty A, Zhong X, Page GP, Zhang H, Ment LR, Gruen JR, Neontal Genetics Study Group (2006) Familial and genetic susceptibility to major neonatal morbidities in preterm twins. Pediatrics 117:1901-1906

Bhatt AJ, Pryhuber GS, Huyck H, Watkins RH, Metlay LA, Maniscalco WM (2001) Disrupted pulmonary vasculature and decreased vascular endothelial growth factor, Flt-1, and TIE-2 in human infants dying with bronchopulmonary dysplasia. Am J Respir Crit Care Med 164:1971-1980

Blackwell TS, Hipps AN, Yamamoto Y, Han W, Barham WJ, Ostrowski MC, Yull FE, Prince LS (2011) NF- KB signaling in fetal lung macrophages disrupts airway morphogenesis. J Immunol 187:2740-2747

Bonikos DS, Bensch KG, Northway WHJ, Edwards DK (1976) Bronchopulmonary dysplasia: the pulmonary pathologic sequel of necrotizing bronchiolitis and pulmonary fibrosis. Hum Pathol 7:643-666

Boström H, Willetts K, Pekny M, Levéen P, Lindahl P, Hedstrand H, Pekna M, Hellström M, Gebre-Medhin S, Schalling M, Nilsson M, Kurland S, Törnell J, Heath JK, Betsholtz C (1996) PDGF-A signaling is a critical event in lung alveolar myofibroblast development and alveogenesis. Cell 85:863-873

Bozyk PD, Popova AP, Bentley JK, Anyanwu AC, Linn MD, Pryhuber GS, Moore BB, Hershenson MB (2012) Neonatal periostin knockout mice are protected from hyperoxia-induced alveolar simplication. PLoS One 7:e31336

Bozyk PD, Popova AP, Bentley JK, Goldsmith AM, Linn MJ, Weiss DJ, Hershenson MB (2011) Mesenchymal stem cells from neonatal tracheal aspirates demonstrate a pattern of lung-specific gene expression. Stem Cells Dev 20:1995-2007

Cardoso WV, Lu J (2006) Regulation of early lung morphogenesis: questions, facts and controversies. Development 133:1611-1624

Chang W, Wei K, Jacobs SS, Upadhyay D, Weill D, Rosen GD (2010) SPARC suppresses apoptosis of idiopathic pulmonary fibrosis fibroblasts through constitutive activation of $\hat{\mathrm{I}}^{2}$-Catenin. J Biol Chem 285:8196-8206

Cheema IU, Ahluwalia JS (2001) Feasibility of tidal volume-guided ventilation in newborn infants: a randomized, crossover trial using the volume guarantee modality. Pediatrics 107:1323-1328

Coalson JJ (2003) Pathology of new bronchopulmonary dysplasia. Semin Neonatol 8:73-81

Coalson JJ, Winter VT, Siler-Khodr T, Yoder BA (1999) Neonatal chronic lung disease in extremely immature baboons. Am J Respir Crit Care Med 160:1333-1346

Coalson JJ, Winter V, deLemos RA (1995) Decreased alveolarization in baboon survivors with bronchopulmonary dysplasia. Am J Respir Crit Care Med 152:640-646

del Moral PM, De Langhe SP, Sala FG, Veltmaat JM, Tefft D, Wang K, Warburton D, Bellusci S (2006) Differential role of FGF9 on epithelium and mesenchyme in mouse embryonic lung. Dev Biol 293:77-89

Deng H, Mason SN, Auten RL (2000) Lung inflammation in hyperoxia can be prevented by antichemokine treatment in newborn rats. Am J Respir Crit Care Med 162:2316-2323

Deng H, Dokshin GA, Lei J, Goldsmith AM, Bitar KN, Fingar DC, Hershenson MB, Bentley JK (2008) Inhibition of glycogen synthase kinase- $3 \beta$ is sufficient for airway smooth muscle hypertrophy. J Biol Chem 283:10198-10207

Deng H, Hershenson MB, Lei J, Bitar KN, Fingar DC, Solway J, Bentley JK (2010) p70 Ribosomal S6 kinase is required for airway smooth muscle cell size enlargement but not increased contractile protein expression. Am J Respir Cell Mol Biol 42:744-752

Dreyfuss D, Saumon G (1998) Ventilator-induced lung injury: lessons from experimental studies. Am J Respir Crit Care Med 157:294-323

Eber E, Zach MS (2001) Paediatric origins of adult lung disease 8: Long term sequelae of bronchopulmonary dysplasia (chronic lung disease of infancy). Thorax 56:317-323

Ehrenkranz RA, Walsh MC, Vohr BR, Jobe AH, Wright LL, Fanaroff AA, Wrage LA, Poole K, National Institutes of Child Health and Human Development Neonatal Research Network (2005) Validation of the National Institutes of Health consensus definition of bronchopulmonary dysplasia. Pediatrics 116:1353-1360 
Fanaroff AA, Stoll BJ, Wright LL, Carlo WA, Ehrenkranz RA, Stark AR, Bauer CR, Donovan EF, Korones SB, Laptook AR, Lemons JA, Oh W, Papile L-A, Shankaran S, Stevenson DK, Tyson JE, Poole WK (2007) Trends in neonatal morbidity and mortality for very low birthweight infants. Am J Obstet Gynecol 196:147.e1147.e8

Furman L, Baley J, Borawski-Clark E, Aucott S, Hack M (1996) Hospitalization as a measure of morbidity among very low birth weight infants with chronic lung disease. J Pediatr 128:447-452

Goss AM, Tian Y, Tsukiyama T, Cohen ED, Zhou D, Lu MM, Yamaguchi TP, Morrisey EE (2009) Wnt $2 / 2 b$ and $\beta$-catenin signaling are necessary and sufficient to specify lung progenitors in the foregut. Dev Cell 17:290-298

Greenough A, Cox S, Alexander J, Lenney W, Turnbull F, Burgess S, Chetcuti PA, Shaw NJ, Woods A, Boorman J, Coles S, Turner J (2001) Health care utilisation of infants with chronic lung disease, related to hospitalisation for RSV infection. Arch Dis Child 85:463-468

Groneck P, Götze-Speer B, Oppermann M, Eiffert H, Speer CP (1994) Association of pulmonary inflammation and increased microvascular permeability during the development of bronchopulmonary dysplasia: a sequential analysis of inflammatory mediators in respiratory fluids of high-risk preterm neonates. Pediatrics 93:712-718

Haq S, Michael A, Andreucci M, Bhattacharya K, Dotto P, Walters B, Woodgett J, Kilter H, Force T (2003) Stabilization of beta -catenin by a Wnt-independent mechanism regulates cardiomyocyte growth. Proc Natl Acad Sci 100:4610-4615

Hennrick KT, Keeton AG, Nanua S, Kijek TG, Goldsmith AM, Sajjan US, Bentley JK, Lama VN, Moore BB, Schumacher RE, Thannickal VJ, Hershenson MB (2007) Lung cells from neonates show a mesenchymal stem cell phenotype. Am J Respir Crit Care Med 175:1158-1164

Hillman NH, Moss TJ, Kallapur SG, Bachurski C, Pillow JJ, Polglase GR, Nitsos I, Kramer BW, Jobe AH (2007) Brief, large tidal volume ventilation initiates lung injury and a systemic response in fetal sheep. Am J Respir Crit Care Med 176:575-581

Hirakawa H, Pierce RA, Bingol-Karakoc G, Karaaslan C, Weng M, Shi G-P, Saad A, Weber E, Mariani TJ, Starcher B, Shapiro SD, Cataltepe S (2007) Cathepsin S deficiency confers protection from neonatal hyperoxia-induced lung injury. Am J Respir Crit Care Med 176:778-785

Hong HH, Uzel MI, Duan C, Sheff MC, Trackman PC (1999) Regulation of lysyl oxidase, collagen, and connective tissue growth factor by TGF-betal and detection in human gingiva. Lab Invest 79:1655-1667

Hussain NA, Siddiqui NH, Stocker JR (1998) Pathology of arrested acinar development in postsurfactant bronchopulmonary dysplasia. Hum Pathol 29:710-717

Jobe (2003) Antenatal factors and the development of bronchopulmonary dysplasia. Semin Neonatol 8:9-17

Jobe AH, Bancalari E (2001) Bronchopulmonary dysplasia. Am J Respir Crit Care Med 163:1723-1729

Kaarteenaho-Wiik R, Kinnula VL, Herva R, Soini Y, Pollanen R, Paakko P (2002) Tenascin-C is highly expressed in respiratory distress syndrome and bronchopulmonary dysplasia. J Histochem Cytochem 50:423-431

Kaarteenaho-Wiik R, Pääkkö P, Herva R, Risteli J, Soini Y (2004) Type I and III collagen protein precursors and mRNA in the developing human lung. J Path 203:567-574

Kazzi SN, Kim UO, Quasney MW, Buhimschi I (2004) Polymorphism of tumor necrosis factor-alpha and risk and severity of bronchopulmonary dysplasia among very low birth weight infants. Pediatrics 114:e243-e248

Kennedy JD (1999) Lung function outcome in children of premature birth. J Paediatr Child Health 35:516-521
Kotecha S, Wilson L, Wangoo A, Silverman M, Shaw RJ (1996) Increase in interleukin (IL)-1 beta and IL-6 in bronchoalveolar lavage fluid obtained from infants with chronic lung disease of prematurity. Pediatr Res 40:250-256

Kramer B, Kallapur S, Newnham J, Jobe AH (2009) Prenatal inflammation and lung development. Semin Fetal Neonatal Med 14:2-7

Kumarasamy A, Schmitt I, Nave AH, Reiss I, van der Horst I, Dony E, Roberts JD Jr, de Krijger RR, Tibboel D, Seeger W, Schermuly RT, Eickelberg O, Morty RE (2009) Lysyl oxidase activity is dysregulated during impaired alveolarization of mouse and human lungs. Am J Respir Crit Care Med 180:1239-1252

Langston C, Kida K, Reed M, Thurlbeck WM (1984) Human lung growth in late gestation and in the neonate. Am Rev Respir Dis 129:607-613

Lassus P, Turanlahti M, Heikkilä P, Andersson LC, Nupponen I, Sarnesto A, Andersson S (2001) Pulmonary vascular endothelial growth factor and Flt-1 in fetuses, in acute and chronic lung disease, and in persistent pulmonary hypertension of the newborn. Am J Respir Crit Care Med 164:1981-1987

Laughon M, Allred EN, Bose C, O'Shea TM, Van Marter LJ, Ehrenkranz RA, Leviton A (2009) Patterns of respiratory disease during the first 2 postnatal weeks in extremely premature infants. Pediatrics 123:1124-1131

Leask A, Parapuram S, Shi-wen X, Abraham D (2009) Connective tissue growth factor (CTGF, CCN2) gene regulation: a potent clinical bio-marker of fibroproliferative disease? J Cell Commun Signal 3:89-94

Li Y, Tullus K (2002) Microbial infection and inflammation in the development of chronic lung disease of prematurity. Microbes Infect 4:723-732

Lindahl P, Karlsson L, Hellstrom M, Gebre-Medhin S, Willetts K, Heath J, Betsholtz C (1997) Alveogenesis failure in PDGF-A-deficient mice is coupled to lack of distal spreading of alveolar smooth muscle cell progenitors during lung development. Development 124:3943-3953

Makri V, Hospes B, Stoll-Becker S, Borkhardt A, Gortner L (2002) Polymorphisms of surfactant protein B encoding gene: modifiers of the course of neonatal respiratory distress syndrome? Eur $\mathrm{J}$ Pediatr 161:604-608

Maniscalco WM, Watkins RH, Pryhuber GS, Bhatt A, Shea C, Huyck H (2002) Angiogenic factors and alveolar vasculature: development and alterations by injury in very premature baboons. Am J Physiol Lung Cell Mol Physiol 282:L811-L823

Martin JA, Hamilton BE, Ventura SJ, Osterman MJ, Kirmeyer S, Mathews TJ, Wilson EC (2011) Natl Vital Stat Rep 60:1-70

Maruhashi T, Kii I, Saito M, Kudo A (2010) Interaction between periostin and BMP-1 promotes proteolytic activation of lysyl oxidase. J Biol Chem 285:13294-13303

McGowan SE, Grossmann RE, Kimani PW, Holmes AJ (2008) Platelet-derived growth factor receptor-alpha-expressing cells localize to the alveolar entry ring and have characteristics of myofibroblasts during pulmonary alveolar septal formation. Anat Rec Adv Integr Anat Evol Biol 291:1649-1661

McGowan SE, Torday JS (1997) The pulmonary lipofibroblast (lipid interstitial cell) and its contributions to alveolar development. Ann Rev Physiol 59:43-62

Merritt TA, Cochrane CG, Holcomb K, Bohl B, Hallman M, Strayer D, Edwards DK, Gluck L (1983) Elastase and alpha 1-proteinase inhibitor activity in tracheal aspirates during respiratory distress syndrome. Role of inflammation in the pathogenesis of bronchopulmonary dysplasia. J Clin Invest 72:656-666

Miller JD, Benjamin JT, Kelly DR, Frank DB, Prince LS (2010) Chorioamnionitis stimulates angiogenesis in saccular stage fetal lungs via CC chemokines. Am J Physiol Lung Cell Mol Physiol 298:637-645

Min H, Danilenko DM, Scully SA, Bolon B, Ring BD, Tarpley JE, DeRose M, Simonet WS (1998) Fgf-10 is required for both limb 
and lung development and exhibits striking functional similarity to Drosophila branchless. Genes Dev 12:3156-3161

Mokres LM, Parai K, Hilgendorff A, Ertsey R, Alvira CM, Rabinovitch M, Bland RD (2010) Prolonged mechanical ventilation with air induces apoptosis and causes failure of alveolar septation and angiogenesis in lungs of newborn mice. Am J Physiol Lung Cell Mol Physiol 298:L23-L35

Munshi U, Niu J, Siddiq M, Parton L (1997) Elevation of interleukin8 and interleukin- 6 precedes the influx of neutrophils in tracheal aspirates from preterm infants who develop bronchopulmonary dysplasia. Pediatr Pulmonol 24:331-336

Noguchi A, Reddy R, Kursar JD, Parks WC, Mecham RP (1989) Smooth muscle isoactin and elastin in fetal bovine lung. Exp Lung Res 15:537-552

Northway WH, Rosan RC, Porter DY (1967) Pulmonary disease following respirator therapy of hyaline-membrane disease. Bronchopulmonary dysplasia. N Engl J Med 276:357-368

Parker RA, Lindstrom DP, Cotton RB (1996) Evidence from twin study implies possible genetic susceptibility to bronchopulmonary dysplasia. Semin Perinatol 20:206-209

Pavlovic J, Papagaroufalis C, Xanthou M, Liu W, Fan R, Thomas NJ, Apostolidou I, Papathoma E, Megaloyianni E, DiAngelo S, Floros J (2006) Genetic variants of surfactant proteins A, B, C, and D in bronchopulmonary dysplasia. Dis Markers 22:277-291

Pepicelli CV, Lewis PM, McMahon AP (1998) Sonic hedgehog regulates branching morphogenesis in the mammalian lung. Curr Biol 8:1083-1086

Popova AP, Bentley JK, Anyanwu AC, Richardson MN, Linn MJ, Lei J, Wong EJ, Goldsmith AM, Pryhuber GS, Hershenson MB (2012) Glycogen synthase kinase-3beta/beta-catenin signaling regulates neonatal lung mesenchymal stromal cell myofibroblastic differentiation. Am J Physiol Lung Cell Mol Physiol 303:L439-L448

Popova AP, Bozyk PD, Bentley JK, Linn MJ, Goldsmith AM, Schumacher RE, Filbrun AG, Weiner GM, Hershenson MB (2010) Isolation of mesenchymal stem cells from tracheal aspirates of premature infants predicts bronchopulmonary dysplasia. Pediatrics 126:e1127-e1133

Qi W, Twigg S, Chen X, Polhill TS, Poronnik P, Gilbert RE, Pollock CA (2005) Integrated actions of transforming growth factor- $\beta 1$ and connective tissue growth factor in renal fibrosis. Am J Physiol Renal Physiol 288:F800-F809

Rajagopal J, Carroll TJ, Guseh JS, Bores SA, Blank LJ, Anderson WJ, Yu J, Zhou Q, McMahon AP, Melton DA (2008) Wnt7b stimulates embryonic lung growth by coordinately increasing the replication of epithelium and mesenchyme. Development 135:1625-1634

Rentz TJ, Poobalarahi F, Bornstein P, Sage EH, Bradshaw AD (2007) SPARC regulates processing of procollagen $i$ and collagen fibrillogenesis in dermal fibroblasts. J Biol Chem 282:22062-22071

Rova M, Haataja R, Marttila R, Ollikainen V, Tammela O, Hallman M (2004) Data mining and multiparameter analysis of lung surfactant protein genes in BPD. Hum Mol Genet 13:1095-1104

Saugstad OD (2010) Oxygen and oxidative stress in bronchopulmonary dysplasia. J Perinat Med 38:571-577

Schultz CJ, Torres E, Londos C, Torday JS (2002) Role of adipocyte differentiation-related protein in surfactant phospholipid synthesis by type II cells. Am J Physiol Lung Cell Mol Physiol 283:L288L296

Sekine K, Ohuchi H, Fujiwara M, Yamasaki M, Yoshizawa T, Sato T, Yagishita N, Matsui D, Koga Y, Itoh N, Kato S (1999) Fgf10 is essential for limb and lung formation. Nat Genet 21:138-141

Serls AE, Doherty S, Parvatiyar P, Wells JM, Deutsch GH (2005) Different thresholds of fibroblast growth factors pattern the ventral foregut into liver and lung. Development 132:35-47

Shannon JM (1994) Induction of alveolar type II cell differentiation in fetal tracheal epithelium by grafted distal lung mesenchyme. Dev Biol 166:600-614
Shennan AT, Dunn MS, Ohlsson A, Lennox K, Hoskins EM (1988) Abnormal pulmonary outcomes in premature infants: prediction from oxygen requirement in the neonatal period. Pediatrics $82: 527-532$

Shi-wen X, Stanton LA, Kennedy L, Pala D, Chen Y, Howat SL, Renzoni EA, Carter DE, Bou-Gharios G, Stratton RJ, Pearson JD, Beier F, Lyons KM, Black CM, Abraham DJ, Leask A (2006) CCN2 is necessary for adhesive responses to transforming growth factorbeta1 in embryonic fibroblasts. J Biol Chem 281:10715-10726

Snider P, Hinton RB, Moreno-Rodriguez RA, Wang J, Rogers R, Lindsley A, Li F, Ingram DA, Menick D, Field L, Firulli AB, Molkentin JD, Marwald R, Conway SJ (2008) Periostin is required for maturation and extracellular matrix stabilization of noncardiomyocyte lineages of the heart. Circ Res 102:752-760

Snyder JM, Jenkins-Moore M, Jackson SK, Goss KL, Dai HH, Bangsund PJ, Giguere V, McGowan SE (2005) Alveolarization in retinoic acid receptor-beta-deficient mice. Pediatr Res 57:384-391

Sohn M, Tan Y, Wang B, Klein RL, Trojanowska M, Jaffa AA (2006) Mechanisms of low-density lipoprotein-induced expression of connective tissue growth factor in human aortic endothelial cells. Am J Physiol Heart Circ Physiol 290:H1624-H1634

Soraisham AS, Singhal N, McMillan DD, Sauve RS, Lee SK, Network $\mathrm{CN}$ (2009) A multicenter study on the clinical outcome of chorioamnionitis in preterm infants. Am J Obstetr Gynecol 200:e371-e376

Speer CP (2003) Inflammation and bronchopulmonary dysplasia. Semin Neonatol 8:29-38

Strandjord TP, Madtes DK, Weiss DJ, Sage EH (1999) Collagen accumulation is decreased in SPARC-null mice with bleomycininduced pulmonary fibrosis. Am J Physiol Lung Cell Mol Physiol 277:L628-L635

Strassberg SS, Cristea IA, Qian D, Parton LA (2007) Single nucleotide polymorphisms of tumor necrosis factor-alpha and the susceptibility to bronchopulmonary dysplasia. Pediatr Pulmonol 42:29-36

STOP-ROP Multicenter Study Group (2000) Supplemental Therapeutic Oxygen for Prethreshold Retinopathy Of Prematurity (STOPROP), a randomized, controlled trial: I. Primary outcomes. Pediatrics 105:295-310

SUPPORT Study Group of the Eunice Kennedy Shriver NICHD Neonatal Research Network, Finer NN, Carlo WA, Walsh MC, Rich W, Gantz MG, Laptook AR, Yoder BA, Faix RG, Das A, Poole WK, Donovan EF, Newman NS, Ambalavanan N, Frantz ID 3rd, Buchter S, Sánchez PJ, Kennedy KA, Laroia N, Poindexter BB, Cotten CM, Van Meurs KP, Duara S, Narendran V, Sood BG, O'Shea TM, Bell EF, Bhandari V, Watterberg KL, Higgins RD (2010) Early CPAP versus surfactant in extremely preterm infants. N Engl J Med 362:1970-1979

Takayama G, Arima K, Kanaji T, Toda S, Tanaka H, Shoji S, McKenzie ANJ, Nagai H, Hotokebuchi T, Izuhara K (2006) Periostin: A novel component of subepithelial fibrosis of bronchial asthma downstream of IL-4 and IL-13 signals. J Allergy Clin Immunol 118:98-104

Tooley W (1979) Epidemiology of bronchopulmonary dysplasia. J Pediatr 95:851-858

Torday J, Hua J, Slavin R (1995) Metabolism and fate of neutral lipids of fetal lung fibroblast origin. Biochim Biophys Acta 1254:198-206

Toti P, Buonocore G, Tanganelli P, Catella AM, Palmeri ML, Vatti R, Seemayer TA (1997) Bronchopulmonary dysplasia of the premature baby: an immunohistochemical study. Pediatr Pulmonol 24:22-28

Vaccaro C, Brody JS (1978) Ultrastructure of developing alveoli. I. The role of the interstitial fibroblast. Anat Rec 192:467-479

Vento M, Moro M, Escrig R, Arruza L, Villar G, Izquierdo I, Roberts LJ, Arduini A, Escobar JJ, Sastre J, Asensi MA (2009) Preterm resuscitation with low oxygen causes less oxidative stress, inflammation, and chronic lung disease. Pediatrics 124:e439-e449

Vi L, Feng L, Zhu RD, Wu Y, Satish L, Gan BS, O'Gorman DB (2009) Periostin differentially induces proliferation, contraction and 
apoptosis of primary Dupuytren's disease and adjacent palmar fascia cells. Exp Cell Res 315:3574-3586

Vicencio AG, Lee CG, Cho SJ, Eickelberg O, Chuu Y, Haddad GG, Elias JA (2004) Conditional overexpression of bioactive transforming growth factor-beta1 in neonatal mouse lung: a new model for bronchopulmonary dysplasia? Am J Respir Cell Mol Biol 31:650-656

Vozzelli MA, Mason SN, Whorton MH, Auten RL (2004) Antimacrophage chemokine treatment prevents neutrophil and macrophage influx in hyperoxia-exposed newborn rat lung. Am J Physiol Lung Cell Mol Physiol 286:L488-L493

Wallace M, Probyn M, Zahra V, Crossley K, Cole T, Davis P, Morley C, Hooper S (2009) Early biomarkers and potential mediators of ventilation-induced lung injury in very preterm lambs. Respir Res 10:19

Walsh MC, Wilson-Costello D, Zadell A, Newman N, Fanaroff A (2003) Safety, reliability, and validity of a physiologic definition of bronchopulmonary dysplasia. J Perinatol 23:451-456

Warner BB, Stuart LA, Papes RA, Wispe JR (1998) Functional and pathological effects of prolonged hyperoxia in neonatal mice. Am J Physiol Lung Cell Mol Physiol 275:L110-L117

Weber B, Borkhardt A, Stoll-Becker S, Reiss I, Gortner L (2000) Polymorphisms of surfactant protein A genes and the risk of bronchopulmonary dysplasia in preterm infants. Turk J Pediatr 42:181-185

Weinstein M, Xu X, Ohyama K, Deng CX (1998) FGFR-3 and FGFR4 function cooperatively to direct alveogenesis in the murine lung. Development 125:3615-3623
Welty SE, Smith CV (2001) Rationale for antioxidant therapy in premature infants to prevent bronchopulmonary dysplasia. Nutr Rev 59:10-17

Welty SE, Smith CV (2003) Antioxidants and oxidations in bronchopulmonary dysplasia: there are no easy answers. J Pediatr 143:697-698

Whitehead G, Burch L, Berman K, Piantadosi C, Schwartz D (2006) Genetic basis of murine responses to hyperoxia-induced lung injury. Immunogenetics 58:793-804

Wright C, Strauss S, Toole K, Burt AD, Robson SC (1999) Composition of the pulmonary interstitium during normal development of the human fetus. Pediatr Devel Path 2:424-431

Wu S, Capasso L, Lessa A, Peng J, Kasisomayajula K, Rodriguez M, Suguihara C, Bancalari E (2008) High tidal volume ventilation activates Smad2 and upregulates expression of connective tissue growth factor in newborn rat lung. Pediatr Res 63:245-250

Wu S, Platteau A, Chen S, McNamara G, Whitsett J, Bancalari E (2009) Conditional over-expression of connective tissue growth factor disrupts postnatal lung development. Am J Respir Cell Mol Biol 42:552-563

Yamada M, Kurihara H, Kinoshita K, Sakai T (2005) Temporal expression of alpha-smooth muscle actin and drebrin in septal interstitial cells during alveolar maturation. J Histochem Cytochem 53:735-744

Yi M, Jankov RP, Belcastro R, Humes D, Copland I, Shek S, Sweezey NB, Post M, Albertine KH, Auten RL, Tanswell AK (2004) Opposing effects of $60 \%$ oxygen and neutrophil influx on alveologenesis in the neonatal rat. Am J Respir Crit Care Med 170:1188-1196 